\title{
Hledání vhodných molekulárních markerů pro rozlišení různých druhů enterokoků
}

\section{ŠÁRKA BOBKOVÁ, DANA BAUDIŠOVÁ}

Klíčová slova: Enterococcus - fekální znečištění - molekulární markery - trasování původu mikroorganismů (MST)

\section{SOUHRN}

Enterokoky patři spolu se zástupci druhu Escherichia coli mezi tzv. indikátory fekálního znečištění, které se používají při hodnocení mikrobiologické kvality koupacích vod. Jejich stanovení se řídí vyhláškou MZ ČR č. 238/2011 Sb. a provádí se kultivačně na selektivních agarových médiích. Je známo, že ne všechny druhy enterokoků jsou fekálního původu a mají tedy prímou souvislost s fekálním znečištěním vody. Pro správné hodnocení kvality koupací vody by bylo vhodné znát i původ těchto bakterií. K trasování původu mikroorganismů (tzv. MST, „microbial source tracking") se s výhodou používá metod molekulární biologie. Pomocí PCR metody Ize amplifikací molekulárních markerů (tj. specifických úseků DNA) odlišit různé druhy enterokokủ. Publikací zabývající se touto tématikou je mnoho, nicméně ve většině studií se k druhovému rozlišení používá pouze jeden marker, a to při práci s prrírodními vzorky nemusí být vždy dostatečné. Pro spolehlivou druhovou identifikaci u prírodních vzorků by bylo výhodnější použít kombinaci několika markerů. Zároveň by bylo vhodné aplikovat poznatky získané z experimentů s čistými kulturami na prírodní vzorky koupacích vod, a to jak čistých, tak fekálně znečištěných. Pro praxi by byly důležité i postupy umožňující PCR ze směsného prírodního vzorku, tedy bez nutnosti předkultivace na selektivních médiích, aby se maximálně zkrátila doba, za kterou je znám výsledek.

Cílem tohoto príspěvku je přehledně shrnout publikované molekulární markery pro identifikaci jak enterokoků, tak př́buzných mikroorganismů, a zhodnotit jejich možné použití v mikrobiologii vody pro rychlé zařazení zástupců rodu Enterococcus do druhů prí analýze prírodních vzorků.

\section{CHARAKTERISTICKÉ ZNAKY ENTEROKOKU゚}

Enterokoky jsou gram pozitivní, kataláza negativní koky uspořádané obvykle do krátkých řetízků. Jsou to chemoorganotrofové, jejichž hlavním koncovým produktem při fermentaci cukrů je kyselina mléčná. Ačkoliv fenotypické a biochemické odlišení enterokoků od ostatních bakteriálních druhů je složité, mezi hlavní znaky tohoto rodu patři prítomnost D antigenu, tolerance k vyšším teplotám (až $45^{\circ} \mathrm{C}$ ) i schopnost růstu v prítomnosti 6,5\% NaCl. Při jejich identifikaci v laboratoři se používají selektivní média, na kterých jsou eliminovány ostatní bakteriální druhy (např. SB médium obsahující azid sodný pro potlačení G- tyček).

Taxonomicky patří mezi Enterococcacae a $v$ současné době zahrnuje tento rod 43 druhů [1]. Typickým zástupcem je E. faecalis. Enterokoky se přirozeně vyskytují v trávicím traktu teplokrevných živočichů včetně člověka i v trávicím traktu některých bezobratlých (korýši, šneci) [2, 3] a byly izolovány i z povrchových sladkých i slaných vod, z půdy či z rostlinné vegetace. Některé druhy (např. E. faecalis, E. faecium) jsou podmíněně patogenní.
Prítomnost enterokoků ve vodě může mít různý původ: bud' jsou přirozenou součástí vodního ekosystému a vyskytuji se tam volně, nebo mohou být asociovány s rostlinnou vegetací (typicky E. mundtii, E. casseliflavus) [4, 5], nebo se zooplanktonem [6], prípadně se mohou do vody dostat z půdy [7]. Dalším zdrojem mohou být odpadní vody či exkrementy živočichů, a to jak obratlovců, tak bezobratlých. Za typické intestinální druhy jsou považovány E. faecalis, E. faecium, E. durans, E. hirae [8].

Jak je z výše uvedeného výčtu patrné, ke správné interpretaci zvýšené hladiny enterokoků ve vodním prostředí by bylo vhodné znát jejich původ.

Metody, které se používají k vystopování původu určitých organismů v prostředí, se souhrnně nazývají „microbial source tracking" (MST). Principem těchto metod je, že určité druhy bakteriíjsou asociovány s určitými hostiteli či prostředím. U enterokoků jsou např. druhy E. faecalis, E. faecium považovány za typické intestinální druhy (ačkoliv byly izolovány i z jiných ekosystémů) a naopak E. mundtii, E. casseliflavus jsou většinou spojeny s rostlinami $[9,10]$. Jednou z metod MST je PCR amplifikace určitých (definovaných) úseků DNA (tzv. molekulárních markerů), na jejichž základě je možné rozlišit enterokoky do jednotlivých druhů. $\checkmark$ tomto směru existuje značné množství literatury týkající se nejen enterokoků, ale i jiných rodů bakterií, a je možné z toho při hledání vhodných molekulárních markerů vycházet.

\section{MOLEKULÁRNÍ MARKERY PRO MST}

\section{Obecná charakteristika molekulárních markerů}

Vhodný molekulární marker pro druhové rozlišení bakterií by měl splňovat několik kritérií:

1. měl by být široce rozšiřen $v$ genomech bakterií, tj. ve většině bakterií by měl mít ortologní gen,

2. na druhou stranu také musí obsahovat úseky unikátní pro daný druh bez možných paralogních genů,

3. jejich velikosti musí být dostatečné pro možná porovnávání, ale zároveň ne príliš dlouhé, aby se daly celé sekvenovat,

4. sekvence musí být dostatečně reprezentativní, aby postihla spolehlivě charakteristiku genomu daného druhu. 
Tabulka 1. Přehled diskutovaných molekulárnich markerů

Table 1. Summary of discussed molecular markers

Gen Produkt genu

Komentář

Reference

\section{Kandidátní geny vzešlé ze studie Zeigler a kol. 2003}

\begin{tabular}{|c|c|c|c|}
\hline \multirow{2}{*}{ recN } & \multirow{2}{*}{ recombinační-opravný protein } & vyhodnocen podle in silico analýz jako nejlepší vhodný molekulární marker & Zeigler, D.R. 2003 \\
\hline & & u enterokoků analyzován v souvislosti s tvorbou biofilmu & Frank, K.L. 2013 \\
\hline lig & DNA ligaza & & Zeigler, D.R. 2003 \\
\hline$d n a x$ & podjednotka DNA polymerazy III & vhodný pro odlišení druhů s redukovaným genomem & Zeigler, D.R. 2004 \\
\hline \multirow[b]{2}{*}{ glyA } & \multirow[b]{2}{*}{ serin hydroxymethyltransferase } & není ortologní gen u rodu Mycobacterium & Zeigler, D.R. 2005 \\
\hline & & $\begin{array}{l}\text { použita jako proba při multiplex ligation-dependent probe amplification } \\
\text { na odlišení } 13 \text { druhů patogenů způsobujících alimentární nákazy }\end{array}$ & So-Young Kim a kol. 2016 \\
\hline cyss & cysteine tRNA synthase & & Zeigler, D.R. 2005 \\
\hline thdF & GTP-vázající thiphene oxidaza & $\begin{array}{l}\text { použit při LATE-PCR assay na detekci } 17 \text { bakteriálních patogenů spojených } \\
\text { se sepsí }\end{array}$ & $\begin{array}{l}\text { Zeigler, D.R. 2006, } \\
\text { Rice, L.M. a kol. } 2013\end{array}$ \\
\hline \multirow{2}{*}{ uvrC } & \multirow{2}{*}{ C podjednotka ABC excisazy } & není ortologní gen u rodu Chlamidia & Zeigler, D.R. 2006 \\
\hline & & podílí se na rezistenci k UV & Ozawa a kol. 1997 \\
\hline ruvB & A podjednotka helikázy & není ortologní gen u druhu Bacillus antracis & Zeigler, D.R. 2006 \\
\hline
\end{tabular}

Geny primárního metabolismu

16SrRNA 16S rRNA

\begin{tabular}{ll}
\hline 23SrRNA & 23S rRNA \\
\hline $\begin{array}{ll}\text { 16S-23S } \\
\text { spacer }\end{array}$ & intergenová oblast mezi 16S a 23S \\
\hline tRNA & intergenová oblast mezi tRNA \\
space & geny \\
\hline$d d l$ & D-ala: D-ala ligase \\
\hline
\end{tabular}

různé části 165 rRNA k odlišení druhů u Bacteroides

především odlišení Enterococcus od jiných rodů

domena $\vee$ k odlišení E. faecalis od ostatních druhů enterokoků

rozlišení enterokoků do 3 skupin navržených Falklamem a Collinsem

odlišení 9 druhů enterokoků

odlišení 4 klinicky významných druhů

specifický primer pro odlišení E. faecalis

odlišení 23 druhů enterokoků

odlišení 17 druhů enterokoků

odlišení většiny druhů enterokoků

odlišení většiny druhů enterokoků, použití spolu s pheS

odlišení většiny druhů enterokoků, použití spolu s rpoA

odlišení enterokoků od většiny klinicky významných bakterií
Bernhardt a Field 2000, Layton a kol. 2006, Haughland 2010, Mieszcin 2009

Tsiodras, S. a kol. 2000

Tyrell a kol. 1997,

Facklam a Collins 1989

Baele a kol. 2000

Dutka-Malen 1995

Harwood a kol. 2004,

Ozawa a kol. 2000

Jackson a kol. 2004,

Layton a kol. 2010

Goh a kol. 2000

Naser, S. a kol. 2005

Naser, S. a kol. 2005

Naser, S. a kol. 2005

Ke, D. 1999

\section{Faktory virulence a geny rezistence}

\begin{tabular}{|c|c|c|}
\hline esp & povrchový protein & využití jako molekulárního markeru u enterokoků nejednoznačné \\
\hline asal & povrchový agregující protein & využití jako molekulárního markeru u enterokoků nejednoznačné \\
\hline gelA & želatinaza & využití jako molekulárního markeru u enterokoků nejednoznačné \\
\hline vanA & D-ala:D-lak ligaza & \multirow{3}{*}{$\begin{array}{l}\text { rezistence k vankomycinu, odlišení především rezistentních vs. citlivých } \\
\text { klinických izolátů }\end{array}$} \\
\hline $\operatorname{van} B$ & D-ala:D-lak ligaza & \\
\hline $\operatorname{vanC}$ & D-ala:D-ser ligaza & \\
\hline
\end{tabular}

Shannon M. McQuaig a kol. 2006

Edyta Golińska a kol. 2013

Edyta Golińska a kol. 2013

Evers a kol. 1994,

Navarro a Courvalin 1994 
Markery diskutované $v$ tomto příspěvku jsou shrnuty $\vee$ tabulce 1. Zeigler a kolektiv porovnávali ve své práci 44 bakteriálních genomů, reprezentujících 16 rodů, za účelem hledání takových genových oblastí, které by mohly být použity obecně na rozlišení bakteriálních druhů. Z celkových analýz nakonec vyplynulo 8 různých genů (genových oblastí), které splňovaly výše uvedená kritéria [11]. Daná studie nezahrnovala genom enterokoků, avšak pracovala mimo jiné s genomy 4 druhů streptokoků, mezi něž se enterokoky původně řadily. Z navržených 8 kandidátních genů byly 4 (recN, glyA, thdF, uvrC) zkoumány i u enterokoků, a to bud'v souvislosti s tvorbou biofilmu (recN), nebo resistence k UV (uvrC) $[12,13]$. Geny glyA a thdF byly použity spolu s jinými geny pro odlišení různých bakteriálních patogenů způsobujících alimentární infekce [14, 15]. Amplifikace recN byla použita i pro odlišení několika druhů streptokoků [16]. Tento gen se tedy nabízí jako jeden z několika vhodných kandidátů též k detekci enterokoků.

\section{Skupiny genů vhodných pro MST}

\section{GENY KÓDUJíCÍ KOMPONENTY TRANSKRIPČNÍHO A TRANSLAČNIIHO APARÁTU}

Geny, jejichž produkty se podílí na expresi genetické informace, tedy na transkripci a translaci, splňují podmínku prítomnosti ortologů (tj. ve všech mikroorganismech, kde jsou prítomné, plní stejnou funkci) a zároveň též obsahují úseky specifické pro daný druh. Proto také 165 a 235 rDNA byly mezi prvními kandidáty na molekulární markery pro MST. Použitím různých oblastí 16S rDNA jako biologického markeru se zabývalo mnoho skupin, a to nejen u enterokoků [17], ale v souvislosti s MST též u bakterií rodu Bacteroides [18, 19]. Bacteroides tvoři významnou část střevní mikroflóry teplokrevných živočichů včetně člověka, a proto o nich také bylo uvažováno jako o možných alternativních indikátorech fekálního znečištění $[20,21]$. Na rozdíl od E. coli a intestinálních enterokoků jsou ale obtižně kultivovatelné. Jejich zástupci jsou druhově specifičtí pro určité hostitele [22], čehož by bylo možné s výhodou využít právě pro MST. Sekvenace 16S rRNA patří stále mezi nejpoužívanější metody pro identifikaci druhů enterokoků, přestože má svoje limity při rozlišení blízce príbuzných druhů, zejména ze skupiny E. faecium [23].

Tsiodras s kolegy analyzoval sekvence genu 235 rDNA kódujícího RNA velké podjednotky bakteriálního ribozomu. Použili doménu V 23S rDNA pro odlišení E. faecalis od ostatních druhů enterokoků [24].

Později si badatelé všimli, že zatímco geny pro 165 a 235 rRNA jsou fylogeneticky velmi konzervované, intergenové oblasti vykazuji větší variabilitu a byly by tedy pro odlišení druhů vhodnější. Na základě srovnání intergenové oblasti mezi 235 a 165 rRNA Tyrell a kolektiv mohli rozlišit enterokoky do tří fylogenetických skupin (I, II, III, navržených dřive Facklamem a Collinsem) [25, 26]. V rámci skupiny II bylo navíc i možné odlišit intestinální druh E. faecium od typicky přírodního druhu E. casseliflavus a druhu E. mundtii. Výhodou tohoto markeru je též fakt, že pro amplifikaci se pro všechny druhy používá jeden pár primerů a jednotlivé druhy se liší velikostí amplifikovaného úseku (úseků).

Obdobně Baele a kolektiv použili intergenovou oblast mezi geny pro tRNA k odlišení devíti druhů enterokoků [27]. Při těchto experimentech použili primery navržené v krajních konzervovaných oblastech tRNA genů, pro amplifikaci oblasti mezi těmito geny. To by mohlo umožnit využití této strategie u mnoha bakteriálních druhů, čemuž nasvědčuje fakt, že obdobná genová oblast byla použita pro druhové rozlišení u streptokoků [28], Acinetobacter spp. [29], Listeria spp. [30] a stafylokoků [31, 32].

Dalším slibným markerem je gen rpoA kódující a podjednotku RNA polymerázy. Bylo ukázáno, že při použití rpoA spolu s dalším markerem - phes (gen pro fenylalanyl-tRNA syntázu) je možné rozlišit 30 druhů enterokoků [33]. Gen rpoA byl též mezi kandidátními geny navrženými Zeiglerem a kol. nicméně s menším skóre než výše zmíněných vybraných osm kandidátních genů. Zdá se však, že pro enterokoky by mohl být na odlišení druhů spolehlivě použit.
Podobně lze gen tuf kódující elongační faktor Tu využít pro odlišení enterokoků od ostatních klinicky významných bakterií [34]. Je třeba ale podotknout, že navržené primery se vázaly též na sekvence ortologních genů u několika druhů Listeria spp. a zástupců rodu Abiotrophia.

\section{GENY KÓDUJíCÍ DALŠí PROTEINY PRIMÁRNIIHO METABOLISMU}

Poroznost je věnována i genům kódujícím proteiny primárního metabolismu, především genům $d d l$, sodA, atpA a cpn60.

Gen ddl kóduje D-ala:D-ala ligázu nezbytnou při syntéze peptidoglykanu. Na rozdíl od amplifikace intergenových oblastí, príi použití genu ddl, byla použita pro různé druhy různá dvojice primerů. Výsledkem PCR byl potom bud’ specifický namnožený úsek DNA odpovídající genu daného druhu, nebo žádný produkt. Nevýhodou této metody je, že v př́padě většího množství druhů znamená identifikace tímto způsobem velké množství jednotlivých PCR reakcí. Použitím ddl jako markeru bylo možné rozlišit čtyři druhy enterokoků (E. faecium, E. faecalis, E. gallinarum, E. casseliflavus) [35]. Harwood a kolektiv později identifikovali ddl úsek, který byl specifický pro odlišení E. faecalis od ostatních druhů. Nicméně odlišení druhého typického intestinálního druhu E. faecium bylo s tímto markerem dost složité a často ani nekorelovalo s výsledky biochemických testů [36].

Na obdobném principu, tedy navržení dvojice primerů specifických pro daný druh v rámci jednoho genu navrhli Jackson a kolektiv 23 párů primerů pro amplifikaci genu sodA kódující superoxiddismutázu závislou na Mn [37]. Tyto primery byly pak použity hromadně $v$ celkem 7 PCR reakcích (multiplex PCR). Layton a kolektiv navíc optimalizovali pozici některých primerů, a tím zvýšili jejich druhovou specifitu [38].

Produktem genu atpA je alfa podjednotka ATP syntázy, tedy enzymu zodpovědného za syntézu ATP. Bylo zjištěno, že tímto markerem je možné rozlišit většinu druhů enterokoků. Pomocí atpA spolu s rpoA a phes bylo možné ještě zvýšit spolehlivost druhového určení a navrhnout kombinaci této trojice markerů spolu s 165 rDNA jako vhodné geny pro typizaci enterokoků [33, 39].

Goh a kolektiv využili degenerovaných primerů k odlišení 17 druhů enterokoků na základě amplifikace genu pro chaperonin (cpn 60) [40].

\section{GENY PRO FAKTORY VIRULENCE A ANTIBIOTICKÉ RESISTENCE}

Je na místě se domnívat, že intestinální druhy enterokoků se mohou od těch volně v prírodě žijících druhů lišit produkcí faktorů virulence včetně produkce adhesinů. Ačkoliv se původně myslelo, že např. povrchový protein Esp s funkcí adhesinu je specifický pro izoláty E. faecalis pocházejících z intestinálního traktu člověka [41], později byl tento protein nalezen i u izolátů ze zvířat či jiných príirodních vzorků $[42,43]$.

Prítomnost genů pro jiné faktory virulence jako např. pro povrchový agregující protein (asa 1) či gen pro želatinázu ( gel E) se lišila i u klinických izolátů jednoho druhu [44]. Z tohoto důvodu by mohlo být použití těchto genů jako markerů nejednoznačné.

Typicky prírodní druhy enterokoků (E. casseliflavus a E. gallinarum) jsou, na rozdíl od druhů izolovaných z klinických vzorků, obecně citlivé k antibiotikům. Geny rezistence se často používají jako markery pro odlišení bakteriálních druhů i rezistentních versus citlivých izolátů především v humánní medicíně. K největším současným problémům antibiotické rezistence u enterokoků patři rezistence k vankomycinu, který byl dlouho podáván při infekcích multirezistentními kmeny především u hospodářských zviŕat. Vankomycin inhibibuje syntézu peptidoglykanu, na jehož syntéze se mimo jiných podílí též výše diskutovaná D-ala:D-ala ligáza (gen $d d l)$. Geny, jejichž produkty jsou zodpovědné za rezistenci $k$ vankomycinu, vanA, vanB, van $C-1$, a van $C-2$ jsou príbuzné $k$ ddl $[35,45,46]$. Proti vankomycin rezistentním enterokokům se $v$ současné době používá antibiotikum linezolid inhibující proteosyntézu. Na resistenci k linesolidu se podílí produkty genů cfr kódující ribozom modifikující enzymy a optrA, jehož produktem je ABC transporter [47]. Avšak použití genů rezistence pro 
rozlišení humánních a zviřecích druhů má svoje limity - geny rezistence se mohou v populaci rychle šírit horizontálním přenosem nebo spolu s transpozičními elementy a jejich přenos úzce souvisí se selekčním tlakem v prostředí. Navíc izoláty enterokoků humánního původu mohou vykazovat značné rozdíly $v$ citlivosti $k$ antibiotikům i $v$ rámci jednoho druhu a jednoho prostředí. Proto použití antibiotických genů jako markerů má pravděpodobně jen omezené uplatnění.

\section{ZÁVĚR}

Příspěvek shrnuje testované a publikované molekulární markery, které byly nebo mohou být použity pro druhové rozlišení enterokoků, což by mělo pomoci při charakterizaci jejich původu v koupacích vodách. Většina studií se zabývá vždy jedním vhodným genem, ale to může být při analýze prírodních navíc znečištěných vzorků nedostačující. Pro spolehlivé zařazení enterokoků do druhů by bylo tedy lepší použít kombinaci několika genů včetně jednoho rodově specifického obsahujícího část 16S rRNA. Naser navrhl použít kombinaci genů rpoA, phes atpA a $16 S$ rDNA pro typizaci enterokoků. Svoje výsledky však ověřoval na čistých kulturách. Bylo by tedy zajímavé přenést tyto poznatky do praxe a ověrit je i na prírodních vzorcích koupacích vod. Kromě toho by z uvedeného výčtu mohl být pro typizaci použit ještě některý z genů navržených Zeiglerem a kolektivem jako např. gen recN prípadně glyA nebo thdF. Pro tyto geny by ale bylo nutné udělat ještě podrobnější in silico sekvenační analýzy. Zdá se, že kromě kódujících oblastí, jsou zajímavé i intergenové oblasti, jako např. oblasti mezi geny pro tRNA. Jejich výhodou je možnost použití universálních primerů v konzervovaných oblastech i možnost srovnání s jinými rody, u nichž byl již tento prístup použit.

Výčet zde prezentovaných kandidátů není zdaleka úplný a v literatuře existuje ještě rada dalších možných genových oblastí, které by bylo možné použít jako např. další geny kódující proteiny primárního metabolismu, nebo naopak repetitivní nic-nekodující sekvence. Některé nebyly uvedeny z praktického důvodu, nebot se nehodily pro jednoznačné odlišení původu znečištění nebo k nim není v současné době dostatek dat (nebylo na ně odkázáno ve více studiích). Je zde však velký potenciál dalších možných kandidátů.

\section{Poděkování}

Tento príspěvek vznikl v rámci projektu TA ČR TJ04000132 Využití metod molekulární biologie kidentifikaci zdrojů znečištění v koupacích vodách.

\section{Literatura}

[1] ŠVEC, P. and FRANZ, C.M.A.P. Part III: The family Enterococcaceae. In: HOLZAPFEL, W.H. and WOOD, B.J.B. (eds.). Lactic acid bacteria. Wiley Blackwell, 2014, p. 171-211.

[2] క̌VEC, P. et al. Characterization of yellow-pigmented and motile enterococci isolated from intestines of the garden snail Helix aspera. J. App. Microbiol., 2002, Vol. 92, No. 5, p. 951-957.

[3] SIGNORETTO, C. et al. Persistence of Enterococcus faecalis in aquatic environments via surface interactions with copepods. Appl. Environ. Microbiol., 2005, Vol. 71, No. 5, p. 2756-2761. DOI: 10.1128/ AEM.71.5.2756-2761.2005.

[4] ŠVEC, P. et al. Enterococcus plantarum sp. nov., isolated from plants. Int. J. Syst. Evol. Microbiol., 2012, 62, Pt 7, p. 1499-1505. DOI: 10.1099/ijs.0.033357-0.

[5] OTT, E.M. et al. Population dynamics and antagonistic potential of enterococci colonizing the phyllosphere of grasses. J. Appl. Microbiol., 2001, Vol. 91, No. 1, p. 54-66. DOl:10.1046/j.1365-2672.2001.01334.x. [6] SIGNORETTO, C. et al. Adhesion of Enterococcus faecalis in the nonculturable state to plankton is the main mechanism responsible for persistence of this bacterium in both lake and seawater. Appl. Environ. Microbiol., 2004, Vol. 70, No. 11, p. 6892-6896. DOI: 10.1128/AEM.70.11.6892-6896.2004.

[7] BYAPPANAHALLI, M. and FUJIOKA, R. Indigenous soil bacteria and low moisture may limit but allow faecal bacteria to multiply and become a minor population in tropical soils. Water Sci. Technol., 2004, Vol. 50, No. 1, p. 27-32. ISSN 0273-1223.
[8] WHITEHEAD, M. and GODFREE, V. Imperial Cancer Research Fund and the Lancet. Lancet, 1997, 350, 9091, p. 1627. DOI: 10.1016/S0140-6736(05)64042-1.

[9] GODFREE, A.F. et al. Faecal streptococci as indicators of faecal contamination in water. J. Appl. Microbiol., 1997, 83, S1, p. 110-119. DOI: 10.1046/j.1365-2672.83.s1.12.x.

[10] MULLER, T. et al. Identification of plant-associated enterococci. J. Appl. Microbiol., 2001, Vol. 91, No. 2, p. 268-278. DOI: 10.1046/j.1365-2672.2001.01373.x.

[11] ZEIGLER, D.R. Gene sequences useful for predicting relatedness of whole genomes in bacteria. Int. J. Syst. Evol. Microbiol., 2003, 53, Pt 6, p. 1893-1900. DOI: 10.1099/ijs.0.02713-0.

[12] FRANK, K.L. et al. AhrC and Eep are biofilm infection-associated virulence factors in Enterococcus faecalis. Infect. Immun., 2013, Vol. 8, No. 5, p. 1696-1708. DOI: 10.1128/IAl.01210-12.

[13] OZAWA, Y. et al. Cloning and genetic analysis of the UV resistance determinant (uvr) encoded on the Enterococcus faecalis pheromone-responsive conjugative plasmid pAD1. J. Bacteriol., 1997, Vol. 179, No. 23, p. 7468-7475. DOI: 10.1128/jb.179.23.7468-7475.1997.

[14] RICE, L.M. et al. Design of a single-tube, endpoint, linear-after-the-exponential-PCR assay for 17 pathogens associated with sepsis. J. Appl. Microbiol., 2013, Vol. 114, No. 2, p. 457-469. DOI: 10.1111/ jam.12061.

[15] KIM, S.Y. et al. Simultaneous Identification of 13 Foodborne Pathogens by Using Capillary Electrophoresis-Single Strand Conformation Polymorphism Coupled with Multiplex LigationDependent Probe Amplification and Its Application in Foods. Foodborne Pathog. Dis., 2016, 13, 10, p. 566-574. DOI: $10.1089 / \mathrm{fpd} .2016 .2143$.

[16] GLAZUNOVA, O.O. et al. Partial recN gene sequencing: a new tool for identification and phylogeny within the genus Streptococcus. Int. J. Syst. Evol. Microbiol., 2010, 60, Pt 9, p. 2140-2148. DOI: 10.1099/ijs.0.018176-0.

[17] DEASY, B.M. et al. A rapid PCR based method to distinguish between Lactococcus and Enterococcus. Syst. Appl. Microbiol., 2000, 23, 4, p. 510-522. DOI: 10.1016/S0723-2020(00)80025-9.

[18] BERNHARD, A.E. and FIELD, K.G. Identification of nonpoint sources of fecal pollution in coastal waters by using host-specific $16 \mathrm{~S}$ ribosomal DNA genetic markers from fecal anaerobes. Appl. Environ. Microbiol., 2000, 66, 4, p. 1587-1594. DOI: 10.1128/aem.66.4.1587-1594.2000.

[19] LAYTON, A. et al. Development of Bacteroides 165 rRNA gene TaqMan-based real-time PCR assays for estimation of total, human, and bovine fecal pollution in water. Appl. Environ. Microbiol., 2006, 72, 6, p. 4214-4224. DOI: 10.1128/AEM.01036-05.

[20] FIKSDAL, L. et al. Survival and detection of Bacteroides spp., prospective indicator bacteria. Appl. Environ. Microbiol., 1985, 49, 1, p. 148-150. DOI: 10.1128/AEM.49.1.148-150.1985.

[21] KREADER, C.A. Design and evaluation of Bacteroides DNA probes for the specific detection of human fecal pollution. Appl. Environ. Microbiol., 1995, 61,4, p. 1171-1179. DOI: 10.1128/AEM.61.4.1171-1179.1995. [22] DICK, L.K. et al. Host distributions of uncultivated fecal Bacteroidales bacteria reveal genetic markers for fecal source identification. Appl. Environ. Microbiol., 2005, 71, 6, p. 3184-3191. DOI: 10.1128/ AEM.71.6.3184-3191.2005

[23] DEVRIESE, L.A. et al. Differentiation and identification of Enterococcus durans, E. hirae and E. villorum. J. Appl. Microbiol., 2002, Vol. 92, No. 5, p. 821-827. DOI: 10.1046/j.1365-2672.2002.01586.x.

[24] TSIODRAS, S. et al. Diversity of domain $V$ of $23 S$ rRNA gene sequence in different Enterococcus species. J. Clin. Microbiol., 2000, Vol. 38, No. 11, p. 3991-3993. DOI: 10.1128/JCM.38.11.3991-3993.2000.

[25] FACKLAM, R.R. and COLLINS, M.D. Identification of Enterococcus species isolated from human infections by a conventional test scheme. J. Clin. Microbiol., 1989, Vol. 27, No. 4, p. 731-734. DOI: 10.1128/ JCM.27.4.731-734.1989.

[26] TYRRELL, G.J. et al. Species identification of enterococci via intergenic ribosomal PCR. J. Clin. Microbiol., 1997, Vol. 35, No. 5, p. 1054-1060. DOI: 10.1128/JCM.35.5.1054-1060.1997.

[27] BAELE, M. et al. Application of tRNA intergenic spacer PCR for identification of Enterococcus species. J. Clin. Microbiol., 2000, Vol. 38, No. 11, p. 4201-4207. DOI: 10.1128/JCM.38.11.4201-4207.2000.

[28] MCCLELLAND, M. et al. Length polymorphisms in tRNA intergenic spacers detected by using the polymerase chain reaction can distinguish streptococcal strains and species. J. Clin. Microbiol., 1992, Vol. 30, No. 6, p. 1499-1504. DOI: 10.1128/JCM.30.6.1499-1504.1992.

[29] EHRENSTEIN, B. et al. Acinetobacter species identification by using tRNA spacer fingerprinting. J. Clin. Microbiol., 1996, Vol. 34, No. 10, p. 2414-2420. DOI: 10.1128/JCM.34.10.2414-2420.1996.

[30] VANEECHOUTTE, M. et al. Comparison of PCR-based DNA fingerprinting techniques for the identification of Listeria species and their use for atypical Listeria isolates. Int. J. Syst. Bacteriol., 1998, 48, Pt 1, p. 127-139. DOI: 10.1099/00207713-48-1-127.

[31] MAES, N. et al. Rapid and accurate identification of Staphylococcus species by tRNA intergenic spacer length polymorphism analysis. J. Clin. Microbiol. 1997, Vol. 35, No. 10, p. 2477-2481. DOI: 10.1128/ JCM.35.10.2477-2481.1997.

[32] WELSH, J. and MCCLELLAND, M. PCR-amplified length polymorphisms in tRNA intergenic spacers for categorizing staphylococci. Mol. Microbiol., 1992, Vol. 6, No. 12, p. 1673-1680. DOI: 10.1111/j.13652958.1992.tb00892.x

[33] NASER, S.M. et al. Application of multilocus sequence analysis (MLSA) for rapid identification of Enterococcus species based on rpoA and phes genes. Microbiology (Reading), 2005, 151, Pt 7, p. 2141-2150. DOI: 10.1099/mic.0.27840-0. 
[34] KE, D. et al. Development of a PCR assay for rapid detection of enterococci. J. Clin. Microbiol., 1999, Vol. 37, No. 11, p. 3497-3503. DOI: 10.1128/JCM.37.11.3497-3503.1999.

[35] DUTKA-MALEN, S. et al. Detection of glycopeptide resistance genotypes and identification to the species level of clinically relevant enterococci by PCR. J. Clin. Microbiol., 1995, Vol. 33, No. 1, p. 24-27. DOI: 10.1128/JCM.33.1.24-27.1995.

[36] HARWOOD, V.J. et al. Molecular confirmation of Enterococcus faecalis and E. faecium from clinical, faecal and environmental sources. Lett. Appl Microbiol., 2004, Vol. 38, No. 6, p. 476-482. DO 10.1111/j.1472-765X.2004.01518.X.

[37] JACKSON, C.R. et al. Use of a genus- and species-specific multiplex PCR for identification of enterococci. J. Clin. Microbiol., 2004, Vol. 42, No. 8, p. 3558-3565. DOI: 10.1128/JCM.42.8.3558-3565.2004.

[38] LAYTON, B.A. et al. Enterococcus species distribution among human and animal hosts using multiplex PCR. J. Appl. Microbiol., 2010, Vol. 109, No. 2, p. 539-547. DOI: 10.1111/j.1365-2672.2010.04675.x.

[39] NASER, S. et al. Phylogeny and identification of Enterococci by atpA gene sequence analysis. J. Clin. Microbiol., 2005, Vol. 43, No. 5, p. 2224-2230. DOI: 10.1128/JCM.43.5.2224-2230.2005.

[40] GOH, S.H. et al. Identification of Enterococcus species and phenotypically similar Lactococcus and Vagococcus species by reverse checkerboard hybridization to chaperonin 60 gene sequences. J. Clin. Microbiol., 2000, Vol. 38, No. 11, p. 3953-3959. DOI: 10.1128/JCM.38.11.3953-3959.2000.

[41] SCOTT, T.M. et al. Potential use of a host associated molecular marker in Enterococcus faecium as an index of human fecal pollution. Environ. Sci. Technol., 2005, Vol. 39, No. 1, p. 283-287.

[42] LAYTON, B.A. et al. Distribution and diversity of the enterococcal surface protein (esp) gene in animal hosts and the Pacific coast environment. J. Appl. Microbiol., 2009, Vol. 106, No. 5, p. 1521-1531. DOl: 10.1111/j.1365-2672.2008.04113.x.

[43] WHITMAN, R.L. et al. Incidence of the enterococcal surface protein (esp) gene in human and animal fecal sources. Environ. Sci. Technol., 2007, Vol. 41, No. 17, p. 6090-6095. DOI: 10.1021/es070817t.

[44] GOLINSKA, E. et al. Virulence factors of Enterococcus strains isolated from patients with inflammatory bowel disease. World. J. Gastroenterol., 2013, Vol. 19, No. 23, p. 3562-3572. DOI: 10.3748/ wjg.v19.i23.3562

[45] EVERS, S. et al. Sequence of the vanB and ddl genes encoding D-alanine:D-lactate and D-alanine:D-alanine ligases in vancomycin-resistant Enterococcus faecalis V583. Gene., 1994, Vol. 140, No. 1, p. 97-102. DOI: 10.1016/0378-1119(94)90737-4.

[46] NAVARRO, F. and COURVALIN, P. Analysis of genes encoding D-alanine-D-alanine ligase-related enzymes in Enterococcus casseliflavus and Enterococcus flavescens. Antimicrob. Agents. Chemother. 1994, Vol. 38, No. 8, p. 1788-1793. DOI: 10.1128/aac.38.8.1788.

[47] SADOWY, E. Linezolid resistance genes and genetic elements enhancing their dissemination in enterococci and streptococci. Plasmid., 2018, 99, p. 89-98. DOl: 10.1016/j.plasmid.2018.09.011.

\section{Autoři}

RNDr. Šárka Bobková, Ph.D.

\sarka.bobkova@szu.cz

ORCID: 0000-0003-3552-2530

RNDr. Dana Baudišová, Ph.D.

凶dana.baudisova@szu.cz

ORCID: 0000-0003-3993-6845

Státní zdravotní ústav

Př́spěvek prošel lektorským řízením.
SEARCH FOR SUITABLE MOLECULAR

MARKERS FOR SPECIES DIFFERENTIATION OF ENTEROCOCCI

\section{BOBKOVA, S.; BAUDISOVA, D.}

National Institute of Public Health

Keywords: Enterococcus - faecal contamination molecular markers - microbial source tracking (MST)

Enterococci, together with representatives of the species Escherichia coli, belong to the so-called indicators of faecal pollution, which are used in the evaluation of the microbiological quality of bathing waters. Their determination is governed by the Decree of the Ministry of Health No. 238/2011 Coll. and performed by culture on selective agar media. It is known that not all types of enterococci are of fecal origin and are therefore directly related to fecal water pollution. To properly assess the quality of bathing water, it would be useful to know the origin of these bacteria. For tracing the origin of these microorganisms (so-called microbial source tracking) the molecular biology methods can be used. Using PCR method, different types of enterococci can be distinguished by amplification of molecular markers (ie specific parts of DNA). There are many publications dealing with this topic, however, in most studies, only one marker is analyzed for species differentiation, and this may not always be sufficient when working with natural samples. For reliable species identification in natural samples, it would be more advantageous to use a combination of several markers. At the same time, it would be appropriate to apply the knowledge gained from experiments with pure cultures to natural samples of bathing water, both pure and faecally polluted. For practice, it would be also important to use procedures enabling PCR from a mixed natural sample, without the need for pre-cultivation on selective media, in order to minimize the time for which the result is known.

The aim of this paper is to summarize the published molecular markers for the identification of both enterococci and related microorganisms, and to evaluate their possible use in water microbiology for the rapid classification of Enterococcus species into species during the analysis of natural samples.

DOI: 10.46555/VTEI.2020.12.005 